Florida International University FIU Digital Commons

3-11-2016

\title{
Edwidge Danticat and Shadows: The Farming of Bones As a Vehicle for Social Activism
}

Jessica Petit-Frere

Florida International University, jpeti003@fiu.edu

DOI: 10.25148 /etd.FIDC000218

Follow this and additional works at: https://digitalcommons.fiu.edu/etd

Part of the English Language and Literature Commons, and the Race, Ethnicity and PostColonial Studies Commons

\section{Recommended Citation}

Petit-Frere, Jessica, "Edwidge Danticat and Shadows: The Farming of Bones As a Vehicle for Social Activism" (2016). FIU Electronic Theses and Dissertations. 2492.

https://digitalcommons.fiu.edu/etd/2492 


\section{FLORIDA INTERNATIONAL UNIVERSITY}

Miami, Florida

EDWIDGE DANTICAT AND SHADOWS: THE FARMING OF BONES AS A VEHICLE FOR SOCIAL ACTIVISM

A thesis submitted in partial fulfillment of the

requirements for the degree of

MASTER OF ARTS

in

ENGLISH

by

Jessica Petit-Frere 
To: Dean Michael R. Heithaus

College of Arts, Sciences and Education

This thesis, written by Jessica Petit-Frere, and entitled Edwidge Danticat and Shadows: The Farming of Bones as a Vehicle for Social Activism, having been approved in respect to style and intellectual content, is referred to you for judgment.

We have read this thesis and recommend that it be approved.

Heather D. Russell

Meri-Jane Rochelson

Donna Aza Weir-Soley, Major Professor

Date of Defense: March 11, 2016

The thesis of Jessica Petit-Frere is approved.

Dean Michael R. Heithaus

College of Arts, Sciences and Education

Andrés G. Gil

Vice President for Research and Economic Development and Dean of the University Graduate School

Florida International University, 2016 


\section{DEDICATION}

I dedicate this thesis to my parents, Guy Renald Petit-Frere and Guirlaine

Michaud. Without their encouragement, their pride in our culture, their sacrifices, their support, and their love, the completion of this work would not have been possible. 


\section{ACKNOWLEDGMENTS}

I would like to thank the members of my committee for their support and patience through this thesis process. It is because of their encouragement that I was able to finally complete this thesis and write a paper that I am proud of. They stood by me and kept me on task even when my faith in myself waivered. Professor Meri-Jane Rochelson has been a motivator since my undergraduate studies and influential in helping me to view multicultural literature as a focus in my studies. Dr. Heather Russell has pushed me to understand and contemplate the history of the enslavement of Africans, its repercussions and the importance of discourse in bringing change. Last but not least, a huge thanks to Dr. Donna Weir-Soley, who made sure I kept working, provided me with resources, and was dedicated to ensuring that I did the best job that I could. She introduced me to The Farming of Bones in my undergraduate studies, creating a space for me to learn more about my culture and myself. For that I can never repay her. I'd also like to thank Katie Pacheco, Jessica Alvarez-Harris, Sherry Danier, Jirdelle Jean-Louis, Frandia Bazelais, Anabel Martinez, Christy Francois, Sashay Goodletty, Kia Mathis, Reanna Saroop, and my Trinity family for their prayers, lectures, and support throughout this process. My God is so good to me and for that I am most thankful. 
ABSTRACT OF THE THESIS

EDWIDGE DANTICAT AND SHADOWS: THE FARMING OF BONES AS A VEHICLE FOR SOCIAL ACTIVISM

\author{
by \\ Jessica Petit-Frere \\ Florida International University, 2016 \\ Miami, Florida \\ Professor Donna-Aza Weir-Soley, Major Professor
}

“The Farming of Bones” is Edwidge Danticat's novel about Amabelle Desir, a Haitian migrant in the Dominican Republic during the 1937 Haitian massacre. The Massacre is a historical fact presented through a fictional text that acts as a testimonial. The purpose of this thesis is to demonstrate how Danticat, in her role as an activist, urges readers to become social justice seekers and enter the discourse of race. Through an examination of Carl Jung's and Vodou's shadow theories in regards to the construction of a racial identity by Haitians and Dominicans, I uncover the racial narratives in place from Haiti's colonization and independence to our current time. Danticat, through the novel, moves the reigning racial paradigm out of the shadow and thus allows readers to reflect on its effects. Thus it is not only the characters in the novel that must confront the shadow, but the readers themselves. 


\section{TABLE OF CONTENTS}

CHAPTER

PAGE

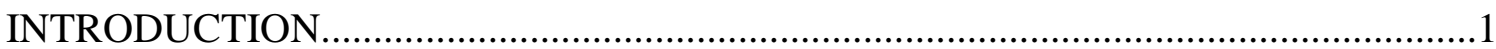

I. SHADOW THEORY AND COMMUNITY IN THE FARMING OF

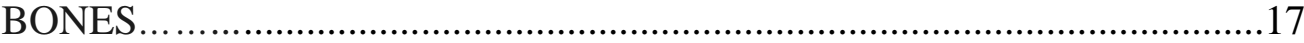

II. TEXTUAL ANALYSIS OF THE FARMING OF BONES............................36

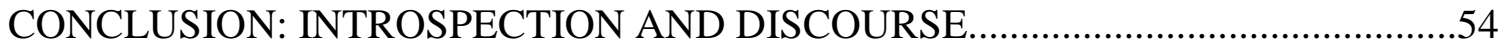

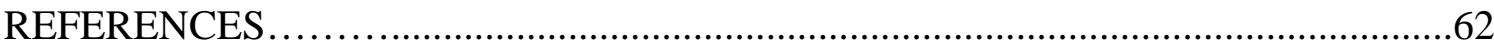




\section{INTRODUCTION}

“I think novels just really show us the deepest parts of people’s hearts, and you cannot walk away anymore and say, “I don’t know.” It’s not the news, it’s not journalism. It’s another more in-depth way of looking at somebody's individuality, which is so often denied to people like us, to people like me, to people who come from places like me.”

- Edwidge Danticat

Since the beginning of her career, Edwidge Danticat's works have demonstrated and exposed the multiple facets of the lives of Haitian people to her readers. Her fiction and non-fiction print work, documentaries via collaborations with other activists, and her own political activism also work to reveal the general lack of awareness about the complex histories, culture, socioeconomic and political experiences of this group of people who inhabit an island less than 700 miles from the American east coast. As a result, over the last two decades, Danticat has proved to be an important and powerful voice within and for the Haitian community. Her works have received multiple accolades not only from the Haitian community but from the national and global community, including but not limited to the National Book Award and the MacArthur Fellows Genius Grant. Danticat focuses on the treatment of Haitians abroad and in Haiti itself, where political and economic growth and development improves at a glacial pace. Haiti's rich history stands in stark juxtaposition to contemporary economic and political realities. Danticat's ability to capture this paradox gives a timeless quality to her works. Danticat's body of work, in its ability to depict the beauty and ugliness of Haitian culture, consistently challenges readers to enter a role of responsibility and raises the question: 
should readers get involved? Should they do something to address the injustices brought about by history, memory, color, race, and class issues plaguing Haitians?

Though it was published nearly 20 years ago, Edwidge Danticat’s 1998 novel, The Farming of Bones, still speaks to the racial tensions that exist between Haiti and its neighbor, the Dominican Republic. The Farming of Bones is a historical fiction that explores the 1937 massacre ordered by Dominican Republic's dictator at the time, Rafael Trujillo. In this novel, as in her other works, Danticat challenges readers to empathize with the characters in the novel through her mixture of history and fiction. My thesis will demonstrate how the works completed by Danticat highlight the necessity for readers to respond to her challenge to become more aware, to empathize and to ignite the potential activist within us all. Here, I discuss how Danticat uses The Farming of Bones, a historical novel which operates as a testimonial, to bring the complicated concerns surrounding Haitian culture and ethnicity, identity, and social factors out of the darkness.

Moving to the United States at age 12 from her native Haiti, undoubtedly had an effect on Danticat's writing and how she views the world and the treatment of Haitians. In a 2004 interview, when asked about the lack of news exposure about Haiti and the tendency to reduce such complexities to sound bites, Danticat stated, "People think that there is a country [where]...these people are only around when they are on CNN...at moments when there's not a coup, when there are not people in the streets, ... the country disappears from people’s consciousness” (The Morning News).Haiti is usually only presented to the global audience to show the effects that disasters have had on the country, whether they are natural disasters, disease outbreaks, or political turmoil. 
Danticat's works can be seen as a vehicle the author uses to get readers and listeners to “see” Haitian people beyond these moments.

Danticat's exposure shows both the beauty and the ugliness of Haitian experiences, a balancing approach not regularly covered by Haiti’s often one-sided portrayal in the media through its disasters. In her book Create Dangerously, Danticat questions what it means to be an immigrant writer and what it means to "create dangerously" in this journey of revealing and uncovering hidden realities. She concurs with the French philosopher, Albert Camus, and poet Osip Mandelstam, that creating dangerously "is creating as a revolt against silence, creating when both the creation and the reception, the writing and the reading, are dangerous undertakings, disobedience to a directive" (11). Danticat essentially creates dangerously with the subject matter of her novels, the articles written, the interviews given, and the documentaries she has chosen to narrate, all of which work against the grain and challenge readers to re-see Haiti, not as a site of normalized disaster, but to engage the country in all of its complexities as a place which necessitates global social justice.

Danticat has spoken publicly about a number of Haitian related concerns, including the role of women in Haitian society, Haiti's involvement in the global economy and political struggles before and after the disastrous earthquake in 2010, and, the racist and unequal immigration policies adopted against Haitians throughout the Haitian diaspora. In the 2009 documentary Poto Mitan, for example, as the writer and narrator, she braids a story about the connection between a grandmother, a daughter and a grandchild against the documentary's depictions of the struggle for Haitian women to become educated and self-sufficient in a global economy that exploits Haitian labor for 
profit. The central narrative depicts Haitian women and their treatment by fellow Haitians and foreign factory owners. The film urges its viewers to consider the cost of the goods they consume which are produced in countries like Haiti against the wages, sacrifices, and exploitative conditions of the very people who produce them.

In addition, Danticat has also written articles to express concerns about what can be done for Haitians in the years following the 2010 earthquake. She has written a fictional children's book and has given multiple interviews about the earthquake all to remind readers that the people affected by the earthquake and their issues are still salient and relevant. Their stories and their struggles have not come to an end, as the earthquake has had residual, long-lasting effects on their lives. These conditions and experiences contribute to the continued influx of Haitians immigrating to other places, such as the United States, where Haitian people are often met with further injustices.

Danticat's 2013 opinion piece in The Washington Post, for example, challenged the detainee process for immigrants in the United States, which comes not only at the cost of taxpayer dollars but the denial of basic human rights. She has been particularly vocal about immigration detention since the death of her uncle, mentioned in several of her works, in Krome Detention Center in Miami in 2004. Although Danticat's work on immigration reforms extends to other groups, such as Mexicans, it also aims to show correlations between difficult experiences in Haiti and upon arrival in new lands. In these new lands Haitian people are further subjected to unfair treatments. Her works in general serve to keep the Haitian people in conversation, making the struggles of many Haitians a very real part of her readers' sense of the world and forcing them to decide whether they 
can bear witness and testify, themselves, or if they can stay silent after what they have read or heard.

The relationship between Haiti and the Dominican Republic (D.R.) has always been a concern for Danticat and has resurfaced as an interest of hers as of late. In the 2007 documentary, The Sugar Babies, produced by filmmaker Amy Serrano and narrated by Danticat, she provides the audience with the opportunity to learn about Haiti's place within the global economy. The Sugar Babies links the exploitation of Africans during the Transatlantic Slave Trade to the 1937 massacre of Haitians in the D.R, and to the continued exploitation of Haitian sugar cane workers who are modern day slaves in the D.R. The film briefly brushes by the 1937 massacre which serves as the setting in The Farming of Bones, to highlight history that the world and even some Dominicans themselves may not know. The documentary sheds light on how, in this $21^{\text {st }}$ century, the sugar industry in the Dominican Republic flourishes under the brutal and careless treatment of Haitian workers. These are the same types of workers and conditions described nearly a decade before the documentary, in The Farming of Bones, and given full expression through Danticat's depiction of characters like Don Carlos, Sebastien, Kongo and others.

The Sugar Babies reinforces what readers familiar with the novel would have learned about how farm workers often lack access to education and proper medical attention, legal documentation, and proper living environments during the zafra, or sugar cane harvesting season. Danticat narrates that, "Annually, more than 30,000 Haitians are lured and illegally trafficked to work in the sugar industry of the Dominican Republic... 
within an illicit web of complicity that involves Dominican and Haitian traffickers, the Dominican military, immigration authorities, and government” (2007).

These are conditions similar to enslavement and, furthermore, the annual number of Haitians lured is approximate to what some researchers believe to be the number of Haitians who were massacred in 1937.This devastatingly ironic synergy between history, fiction, and documentary cannot be ignored. Because the trafficking of Haitian workers has been happening since the US occupation of Haiti in the early 1900’s, many Haitian children have been born and raised in the Dominican Republic, never seeing or truly knowing Haiti, but yet denied valid documents to be considered Dominican citizens because of their Haitian descent. "It's a terrible expression of the xenophobic sentiment there is in this country,” highlights Father Christopher Hartley in The Sugar Babies (2007). Hartley remains concerned and angered by the denial of citizenship to Dominicans of Haitian descent by the Dominican Republic. These xenophobic sentiments are what Danticat continually wants readers to interrogate and reject.

In fact, The Sugar Babies and The Farming of Bones are examples of Danticat's activism vis-à-vis the Dominican government's historic and contemporary treatment of Haitians. As recently as 2013, the Dominican Republic’s Supreme Court gave an order stripping Dominican citizenship or rights from children born in the Dominican Republic to Haitian immigrants as far back as 1929. Legally, the Dominican-born individuals of Haitian descent were given about two years to try to register and obtain legal approval to be in the Dominican Republic. Films like The Sugar Babies help us to understand why obtaining such documentation is extremely difficult for the majority affected. How can you gain legal documentation to prove citizenship when you have been historically 
denied that very documentation? Danticat does not deny the economic and political complications in the history between the Dominican Republic and Haiti, yet she urges people to see how history has also informed certain views and how damaging the policies being adopted have been to the Haitian people. What is our role then as spectators? In response to outrage over the law and to journalist Randal C. Archibold's coverage of the events, Danticat, along with Dominican-American writers Junot Diaz and Julia Alvarez, wrote a letter to the editor in the October 31, 2013 opinion page of The New York Times. “How should the world react? Haven’t we learned after Germany, the Balkans and South Africa that we cannot accept institutionalized racism?” they wrote (“Two Versions of a Dominican Tale"). Also in response, Aníbal De Castro, Ambassador of the Dominican Republic at that time wrote, "Unlike the United States, the Dominican Republic does not grant citizenship to all those born within its jurisdiction.” He argued that Haiti, on the other hand, grants Haitian citizenship to those born outside of the country so the people affected by this decree would not be stateless.

Though the law was created in 2013, the deadline to register and obtain an approval to be in the country was not reached until 2015. In 2015, in the Dominican Republic, this law created to support the deportation of thousands of people from the Dominican Republic to Haiti finally came to the media forefront. In an October 2015 Miami New Times article, Danticat is quoted as saying, "I think going back that far [1929], it's almost as if [the Dominican government] is trying to erase this whole segment of history and population of people... It's going back even before they had this huge recruitment of people to work on the sugarcane fields” (De Greff). 
Furthermore, in the summer of 2015, here in Miami, Danticat and Diaz once again reunited to speak on this very subject. "If you're not concerned, you should be” Danticat urged. Referencing the context of The Farming of Bones, she remarks in a comment to Fusion, a media company, that 1937 was a historical scar "but [that] we can’t let that overshadow the moment we're living, which is potentially as tragic...It's a humanitarian crisis ready to happen” (“Junot Diaz and Edwidge Danticat”). The 1937 massacre is history but it is clear that the injustice still carries into the present, and if not addressed will continue into the future.

The Dominican Republic's relationship with Haiti is defined by a cycle of identity complexes and power. One island was colonized by two separate groups, the French and the Spanish, fighting for more land and with different methods of how to work that land. Slave labor was brought in and these enslaved Africans would overthrow their colonizers in Haiti. Eugenio Matibag, author of HaitianDominican Counterpoint: Nation, Race, and State on Hispaniola, argues that there are five historical moments that have altered the interaction between the Dominican Republic and Haiti (8-10). The first major juncture between the two countries occurred through the interrelations of the natives, French settlers, Spanish colonizers, and the enslaved Africans across both colonies within the colonial period. After the Dominican Republic freed themselves from Spanish rule in 1822, the country was ruled by the Haitian government for 22 years leading to a second juncture. Clashes arose from this history and contributed to the Dominican issues with Haiti, blackness, African identity and internalized racism about the inferiority of this African identity, especially during the American occupation of the two 
countries in the third juncture. Trujillo's reign came at a time when the Dominican Republic was trying to establish itself as a viable candidate in the global economy, which constitutes the fourth juncture leading to our current moment. Haitian labor is and was needed to fuel this economy but not the stigma associated with the proud black nation. This fear of Haitians and this clear reminder of the ties to an African identity coupled with the dependency on these very people produce a curious psychology and vicious cycle of attraction, dependency and yet maltreatment and rejection that is examined and exposed by Danticat in The Farming of Bones.

The Farming of Bones introduces readers to color consciousness and colorism in the Caribbean, and specifically on the island of Hispaniola. It highlights how color divides both the characters and the Haitians and Dominicans on the island. I argue that, in a subtle and yet urgent voice, Danticat draws the readers, witnesses to Amabelle's experience, into a state of unease and unrest about colorism and how xenophobic sentiments have affected and shaped both the Dominican Republic and Haiti. The text forces readers to enter the discourse and to grapple with the history of color as it is tied to slavery, colonialism and neo-colonialism and its continual impact upon the lives of Haitians in the Dominican Republic and in Haiti.

In the first chapter of the thesis, I marry Jungian and Haitian shadow theory, to illuminate Danticat's thematic concerns. According to Swiss psychiatrist Carl Jung, the shadow seeks to explain how individuation is created. It is in the unification or acceptance of both the conscious and unconscious or darker part of the self that individuation is created. Haitian shadow theory meanwhile considers the role of the ancestral spirit in individuation. It complicates the understanding of the shadow, not as 
something dark or crippling from the onset, but as something to empower and strengthen the self even before confrontation occurs. The Farming of Bones is a text that covers issues of identity having to do with lightness versus darkness. The history of the two countries has marred their sense of identity and foreclosed the possibility of unification despite the fact that they reside on the same small island of Hispaniola. According to Jorge Duany in "Racializing Ethnicity in the Spanish-speaking Caribbean:” " the omission of blackness from the national imagery of the society projects blackness onto an external "other" (222). On one side, the Dominican struggle for identity rests on the basis of the rejection of an African heritage. On the other side, though Haiti has embraced the role enslavement had on their island, perhaps because of their historical victory, their sense of identity is tied up in their role as the rejected party fighting for recognition. Jung's shadow recognizes both the strengths and the weaknesses of one's personality. It has often been used to examine the individual and yet has evolved over time to also include the collective shadow.

Chapter one will examine both the personal shadow which aims at achieving individuation and the collective shadow which takes into account the ever changing communal identities. The collective shadow can then be used to study history and a country's behavior patterns and relationship with other countries because of its own personal history. This particular shadow lurks behind a group of people, which in this case will be the Dominican and Haitian national identity, and informs the way the two countries relate to each other. By looking closely at how history and the resulting shadows have affected the lives and thought processes of the characters and the characters' attempts at confronting these shadows, we as readers gain perspective on the 
value of these confrontations, the complicated history between the Dominican Republic and Haiti, and how these complexities relate to racial identity.

My desire to look at both the personal and collective shadow in The Farming of Bones stems from Jean-Luc Nancy's ideas on community. Nancy, a French philosopher, viewed the world as a global community where individuality is always already tied to the relationship with others. In his essay “Eulogy for the Mêlée,” Nancy’s core point is the idea that identity and the mélange, or mixture, cannot be pinned down as they are "always already gone... shared by all, between all, through one another" (149). In the context of The Farming of Bones, this means that the idea of an ethnic cleansing and a complete separation of the Dominican from the Haitian simply cannot come to pass as it is a fight against the Dominicans' own identity. In other words, to kill "Haitians” is to kill themselves. For Nancy, "Identity is by definition not an absolute distinction, removed from everything, and therefore distinct from nothing: it is always the other of another identity” (149). The work of confronting the personal and collective shadow serves to illuminate why some national ideas that are in place and how such ideals may help or hinder a global community where people are recognized as different, yet same.

Yet looking at The Farming of Bones through the lens of the shadow theory is further complicated by the space which the characters of the novel occupy. Haiti’s strong tie to Africa, as a formerly enslaved nation, is the very reason for the divide between Haitians and Dominicans in the first place. As I worked through the lives of the characters and call attention to Danticat's aim at igniting a response from her readers, I consider the implications of using a primarily Western philosophy with which to analyze the characters. I also acknowledge that the rich references to the Haitian culture in 
Danticat's novel necessitate the integration of the Caribbean concept of the shadow to resist the language used to discuss the Jungian shadow. Jung’s Western theories employ language that is ridden with references to color in terms of what positive and negative shadows are and the theory essentially rests on the idea of merging the good, the bad, the light and the dark to achieve individuation. Zweig reflects that "Even our language reflects this problematic issue in the use of the words 'shadow' and 'dark side', which unfortunately have racial overtones and imply the superiority of whiteness” (54). Vodou shadow theory does not rest on the kinds of dichotomies so central to Jungian philosophy. The Vodou religion, which has deep roots in Haitian culture, comes with its own idea about the shadow. These ideas, read alongside Jung's theory, provide generative material for reading Danticat's text. The Vodou religion takes into account the ancestral spirits' connection to the conscious self. Where Jung's theory may aim toward the reconciliation of the conscious self to the shadow self, Vodou shadow theory emphasizes the inability to live separate from the shadow that is always already a part of the conscious and unconscious self. The two ideologies work together in providing the context of the shadow as a real and tangible part of the self that must be named and confronted to cultivate discourse and further explore race relations and color prejudice.

In The Farming of Bones, it is not only Danticat's use of richly drawn characters, but also her unique style of writing and the weaving of the conscious and unconscious experiences of the characters that lend themselves well to these theoretical approaches. Danticat's book, once read, can be viewed as a vehicle to bring the color tensions between the Dominican Republic and Haiti to light. More so, Danticat's stylistic choice of having chapters dedicated to both dream sequences and reality, the present and the 
past, reflect the way her work intentionally moves between the conscious and unconscious.

In the final chapter of the thesis, I examine Danticat's depiction of the characters' lives, the national identities presented, and their resulting effects on each other. I look into the uneasiness that settled across the town of Alegría with the impending massacre, the journey through the massacre from the Dominican Republic to Haiti, and the national ideologies shared by the characters. Danticat begins the novel with an exultation of black love and self-identity. We are introduced to Amabelle's past habit of playing with her shadow, an act her father warned her against. The opening sequence continues with the birth of Señora Valencia’s twins, Rafael and Rosalinda. Señor Pico's haste to be there for the births, we later find out, has accidently caused the death of Joel, the son of Kongo, a Haitian cane field worker living and working in the Dominican Republic. Joel's death is overshadowed by the birth of the twins and yet, in terms of sequence, it occurs first and works as a foreshadowing of the expendability of the Haitian life in the Dominican Republic. Joel is indeed the son of Kongo, the son of Africa, who is literally tossed aside to make a way for the Dominican future. This Dominican future features twins who, while birthed from the same mother, radically differ in skin tone and physical features, standing in, symbolically for the two nations who share the same land. The birth of the twins is in conversation with Nancy's theory of the community where being cannot exist without the other. There, Danticat creates a space for the twins to co-exist, but it becomes clear to readers that although they can co-exist, one twin has apparently tried to remove the other. The very idea that there is an attempt to separate and to demonstrate that community can be formed on the basis of set, rigid identities, is ultimately what divides 
the twins. It is in the non-communing communities, where the individual "I" and the individual "community" recognize that there is no being without the other that creates the space of being.

Danticat also demonstrates the dire implications of absolute community by letting readers listen in on the complaints of the non- vwayajé Haitians. These people have been rooted in the Dominican Republic for years and generations, yet cannot truly claim the Dominican Republic as home. Once the massacre begins, readers experience the confusion of Amabelle and other characters introduced as they try to come to terms with "the cutting." El corte, or the cutting, is the name given to the massacre by Dominicans as though it was a small cut rather than a gaping stroke of a sword, or "kout kouto”, as it is called by the Haitians indicating a massacre that killed many, not a mere cutting. It is not an experience that is easily forgotten by the characters who must confront the horror of what has happened. While some are able to perform this confrontation, like Amabelle, others do not survive it.

The confrontations they perform are a reflection of the personal and individual shadows that Amabelle and the other characters must confront as they sort their identities. However, these shadows are also the result of the collective shadow at work, a notion I will explore through a close reading of The Farming of Bones as well. If we are to examine the Dominican Republic and Haiti in terms of the Jungian shadow, of a light versus dark, or a dominant versus weak entity, then it is necessary to look at the thoughts and actions of their leaders as a reflection of the national identity. The ideas of the two countries are expressed through an examination of Trujillo's words and actions and those of the Haitians Henri Christophe, a central historical figure, and Stenio Vincent, president 
of Haiti at the time of the massacre. It is important to also contextualize what is happening in the text as we use historical content to fill in the lines within the historical revisionist text that Danticat provides. We as readers are able to see the conversation between the national identities and how they interact with and differ from each other.

The result of these different shadow confrontations, whether we are to look at personal confrontations or collective shadow, is a compulsion by Amabelle to share these horrific experiences, a compulsion to confess. Amabelle is compelled to go back to the Dominican Republic after years of living in Haiti. Trujillo is now gone, but the collective shadow he amped up and fed, still has a hold on the Dominican people. They have gotten rid of the dictator that turned on them, but they themselves have not turned from the idea of a hierarchical difference between those of lighter and darker skin tones. This colorism is further demonstrated by the scene in which Amabelle reunites with Señora Valencia, the twins' mother. Señora Valencia tries to justify what had happened during el corte, the cutting. She explains that she hid Haitians in her home in Amabelle's name because she could not find her. Here, Valencia's reasoning is steeped in the language of the individual and not in the language of an ethical way of being in community. She further tries to justify Trujillo’s actions by asserting that she lived in a time of massacres, where her husband only followed orders, and denouncing her country would be like denouncing herself. The false sense of "patria", the sense of nationalism, is an implicit agreement with a community that exists because of the creation of a specific identity. Valencia's silence gives consent to and opens a space for genocide to enter and remain as a possibility. 
Yet Amabelle has moved past the stage of needing Señora Valencia's approval or false sense of security. By the end of the narrative, Amabelle seeks passage and entrance back to the spring connected to the Massacre River, the northerly body of water bordering the two nations, which gets its name from an $18^{\text {th }}$ century war between the Spanish and French, but whose name ironically portends the 1937 massacre. At the source, she adds her story to the thousands of other stories carried by the body of water. Her story/their story connected cross-temporally must also be told. Amabelle decides to confess to Metrès Dlo, the water spirit, mother of the river. Her confession to Metrès Dlo, is also a confession to us as readers that have peered into her life. With this confession, as readers, as spectators, it is our turn to act. As we readers confront this jarring and tragic look at the effects of an institutionalized denigration of black people, we can examine our own racial constructs. The challenge to the apathy of the bystander, marked by moral indignation, and an urgent call for social justice, I argue, epitomizes the works of Edwidge Danticat. It is not merely enough for readers to read her work, but our role as readers, as witnesses to the testimony of Amabelle, and so many others, should encourage us to enter into the difficult conversation about the brutal limits of race, nation, and discourse that Amabelle has given us entry into at the very river connected to a history of enslavement, death, victory and life. 


\section{SHADOW THEORY AND COMMUNITY IN THE FARMING OF BONES}

"If I lose the light of the sun, I will write by candlelight, moonlight, no light. If I lose paper and ink, I will write in blood on forgotten walls. I will write always. I will capture nights all over the world and bring them to you.”

- Henry Rollins

Edwidge Danticat's 1998 novel, The Farming of Bones, has been the subject of many studies of traumatic memory, nation, history and violence. ${ }^{1}$ The main character, Amabelle Desir, is a Haitian migrant who resides in the Dominican Republic. The 1937 massacre ordered by Generalissimo Rafael Trujillo, forces her to go back to Haiti, a land to which she has not been since the death of her parents when she was a child. The massacre was the result of years of unresolved conflicts by the two battling nations that inhabit the one island. Racial and political tensions reached their peak and resulted in the deaths of 12,000-35,000 Haitians and Dominicans caught in the crossfire (Matibag 139).

Bearing in mind that The Farming of Bones is a historical novel derived from the 1937 massacre, it is imperative that I introduce the historical relations between the Dominican Republic and Haiti that fomented the conflict. After Columbus landed on the island in 1492, he sought to use indigenous Taino labor to generate profit for Spain. Though the indigenous people's interaction with the Spaniards yielded many offspring, many of the indigenous Tainos died as a result of European diseases and maltreatment from the colonizers. The Spanish soon turned to Africa to obtain labor for the coffee and sugar plantations they established. Spain's focus on other new territories allowed for the

\footnotetext{
${ }^{1}$ See Shemak and Simoes for additional analysis of this trend.
} 
French to get a stronghold of the western third of the island, which was ceded to the French in 1697. Hispaniola, the island made up of Haiti and the Dominican Republic, was continuously conquered, divided and redefined between the 1700s and the 1900s, eventually fueling a divide in the perceptions of race and identity as they were constituted in the two nation-states. Haiti became known as the "Pearl of the Antilles," as the economy boomed. The enslaved colony eventually revolted and gained their independence from France by 1804. As a result of the revolution, many people from the eastern section, later known as the Dominican Republic, were killed, as the French/Spanish border was the scene of many battles fought during the war for independence.

The Dominican Republic meanwhile won its independence from Spain in 1821, seventeen years after Haiti declared its own independence from the French. In an effort to protect the hard-won Haitian liberation and deter invasions from the eastern side of the island, Haiti invaded the Dominican Republic in 1822 and occupied the country until 1844, when Haitian control was overthrown. After another period of Spanish rule, from 1845 to1864, Spain finally left the Dominican Republic in 1865. As time passed, the battle over the border between the two nations would continue to be problematic for Haitian-Dominican relations. Between 1874 and 1912, there were at least eight efforts to define the lines and it was not until 1929 that a permanent border was drawn (Wucker 4246). Not coincidentally, 1929 is the year chosen by the Dominican Supreme Court as the date of national demarcation in their 2013 attempt to denaturalize and deport Dominicans of Haitian descent from the Dominican Republic. With this new marker in 1929, there 
were many Haitians now living on Dominican land and they remained in place, having built their lives in their new homeland.

With an unstable political climate that resulted from conflicts about the way that Haiti should be governed and a plunge in economic progress as Haiti began living out its independence by being forced to pay the French 90 million francs, over a hundred-year period, to compensate for France’s loss of a colony, Haiti was predictably on its way to becoming one of the world's poorest nations. With more favorable political allies and help from the United States, the Dominican Republic’s economy improved and surpassed that of its neighboring country. As a result of Haiti’s economic crisis, many Haitians migrated and continue to migrate to the Dominican Republic to find work and a new way of life.

However, as shown in The Sugar Babies, the allure of the promise of economic opportunities through the sugar industry has led Haitians to another period of enslavement, denial of citizenship, being barred from adequate schooling, and entrapment, a vicious cycle which persists until they are no longer of use and then deported. The cycle has continued to the present. Dominicans struggle with coming to terms with their own history of enslavement and with their continued enslavement of Haitians. There is a perpetuating narrative that Haitians are migrating because Haiti is so poor, but not that Haitians are being lured and misled into conditions in the Batey, which are worse than in Haiti. This allure and misleading invitation is an important part of the narrative that does not receive the same amount of attention as the fact that Haiti is a poor nation. Yet, it is clear that the racial paradigms run deep in the Dominican Republic. Spain is not the colonizer in their history. Haiti is the antagonist to Dominican liberation 
and identity in the dominant narrative. While other Caribbean nations celebrate their Independence Day as the date of liberation from their Western colonizers, the Dominican Republic's independence as a sovereign state is heralded as February 27, 1844. This is the date that marks their independence from Haiti.

Readers of The Farming of Bones, are clued in to the fact that these predating issues exist and need to be explored to fully engage the narrative through Amabelle's musings and the conversations held by the characters. It is with teh context in mind that the story of Amabelle Desir is presented. When she was 8, Amabelle’s parents died trying to cross the river to go cauldron shopping in Haiti. She is found by Don Ignacio, and brought to live and serve their family as a companion to his daughter, Valencia. Amabelle grows up in the servant quarters with a loyalty to this family and often interacts with fellow Haitians in the neighboring town and in the sugar cane fields. She meets and falls in love with Sebastien, a cane worker, who tries to encourage her to see the impending danger of being Haitian, or of Haitian descent in the Dominican Republic. Amabelle at first seems to reject this idea and it is not until she is asked to leave for her safety by the Dominican Doctor Javier that she agrees to do so, telling Sebastien that they should go. While tending to Señora Valencia's medical lapse after the birth of her twins, and the burial of her son, the massacre of the Haitians and Dominicans of Haitian descent in the Dominican Republic begins. By the time that Amabelle makes it to where Sebastien and his sister Mimi would have been, they are gone and she has witnessed the capture, torture and death of other Haitians and Dominicans of Haitian descent. Sebastien's friend Yves helps Amabelle escape, navigating their way through the Dominican Republic, across the river, and into their hometown in Haiti, Cap-Haitien. There, they settle back into a life in 
Haiti, haunted by the events that have transpired and led to their return to a place Amabelle had left when she was a young child. Twenty-four years after the massacre, Amabelle returns to Alegría to confront the past.

Through the narrative, Danticat places readers in the role of the witness, as she recounts the life of Amabelle. We, as readers, observe the atrocities and the tragic occurrences in the life of the main character and see, through Amabelle's eyes, how the massacre affects the lives of her friends and acquaintances. Amabelle actively wrestles with the "shadows" that inform her experiences from a young age to the novel's end. The "shadows" represent the personal and culturally hidden parts of her reflected or projected in her conscious and unconscious self. I posit that these fictional confrontations with the shadows allow readers to see the reality of the role that colonization has had on color politics in Haitian-Dominican social, political, and economic relations and to interrogate how Haiti is seen and thought about in the global imaginary.

The theories of Carl Gustav Jung, perhaps the best-known voice in this area of scholarship on the shadow, or shadow aspect, are the launching point, or context and backdrop, upon which an interpretation or reassessment of the shadow can be made. We begin with a look at Jung's study of the correlation between confronting the shadow and coming to terms with one's identity. The process of individuation, according to Jung, results from reconciling both the negative and positive sides of the personality, the conscious and unconscious, a lifelong process (Mattoon 172-180). The conscious self exists in contention with the unconscious self, which holds characteristics that the conscious self does not want to accept or confront. Everyone, according to Jung, has this 
predominantly dormant part of the self that they may or may not be in direct contact with. The shadow is then the "other," the mainly hidden part of the self.

In The Farming of Bones, we are presented with fragments, snapshots of Amabelle's life and reflections. The shadows, the unwanted or dormant parts of her reality are presented as fragments as well. Amabelle is often chastised by Sebastien, her lover, about her inability and unwillingness to confront the subservient part of her personality. “'Who are these people to you? ... Do you think they're your family?'” he asks her (110). She has moments or flashes of clarity that are often suppressed by her desire to live an idle life free of complexities. "Perhaps I had trusted too much. I had been living inside dreams that would not go away, the memories of an orphaned child. When the present itself was truly frightful, I had perhaps purposefully chosen not to see it,” Amabelle ponders (143). These moments of clarity conveyed through Amabelle's snappy remarks and observations, are the "other" manifesting itself.

Yet, depending on the environment of the subject and the acceptable norms of the society or group that they are a part of, the shadow can be either positive or negative. According to Casement, "in analysis, personal shadow problems...will manifest in the transference where patient/analysand may experience the analyst... as a rival either to be competed with or be subservient to" (95). The idea of transference is particularly of interest in examining the dynamics of the relationship between Haiti and the Dominican Republic. The two countries make up Hispaniola, yet their history as neighbors is tangled up in differing understandings of the self and of race. While one country extols black pride, the other distances themselves from a black identity. The Dominican Republic plays the role of the patient/analysand, as the aggressor in the massacre, while Haiti plays 
the role of the analyst. The analyst is seen as a competitor that must be conquered. The sense of competition creates an almost irrational fear which arises that if not conquered, then the patient must then be subservient; in this case, the nation either crushes or submits to ita neighbor. Haiti then represents the competition in terms of land, population and culture while the Dominican Republic struggles to retain a separate and alternate identity that it fears will be swallowed up by Haiti if its people are not stopped. For example, Trujillo, according to Wucker, "launched a massive propaganda campaign to portray himself as the savior of Dominican nationhood: Catholic, white and oriented to Europe” (52). Implicit in the public discourse is the idea that Haitian nationhood is constituted by the opposite: Vodou, black, and oriented to Africa. The two nations may share many moments in history with each other, but the racial ideologies are unique to each country. This notion of a hierarchy in race is reflected through the patronizing and dismissive relationship of Señora Valencia and her husband towards their workers and Trujillo’s complex relationship with Haitians in the novel.

In the case of The Farming of Bones, the way that Trujillo and his followers justify their genocidal actions does not stem solely from Trujillo’s personal battle with the shadow, but is reflective of a collective Dominican shadow. The personal shadow is connected to much more than one's particular experiences in life. As a response to the other social influences, Jung, also introduces the idea of the collective unconscious. In Jungian thought, the collective unconscious, like the personal unconscious, houses distasteful characteristics. However, the collective unconscious stems from a group experience, rather than a personal experience, which creates a collective shadow. As a nation, in 1937, the Dominican Republic had adopted Trujillo’s indoctrination of an 
alternative narrative of identity to examine and understand the Haitian presence. Zweig and Wolfe argue that "Our cultural shadow projection- we are light, they are dark-falls upon different groups at different times” (54).

One of the most compelling examples of the collective shadow and unconscious at play lies with Nazi Germany. The Nazis' projection onto the Jews as the cause of their issues deemed the Jews as inferior and evil people that deserved the gas chambers (Casement 96). Many contend that it is in fact the Germanic inferiority complex that led to the genocide. The internalization of inferiority was a result of rampant poverty, high unemployment rates, World War I outcomes, and, as Jung thought, even from the belief that they were behind the British and the French in establishing their nation. In other words, Jung argues that Germans felt that they came late in the game of acquiring colonies (Gellert 5-6) and thus power. In a similar vein, the history of Haiti and the Dominican Republic during Trujillo's reign, suggests that there are parallels to be made between the 1937 massacre and Nazi Germany in terms of the genocidal impulses of the collective shadow at work. It is not to say that the 1937 massacre falls on the same scale of atrocities carried out by the Nazis, but it is important to recognize that $12,000-35,000$ people were killed in 1937. Similar to the German case, poverty, unemployment rates and Dominican Republic's place in history in comparison to Haiti's status as the first free black republic, played a role in fomenting the massacre as well.

The massacre stemmed from a desire to discursively, imaginatively, and materially remove and eradicate the African blood coursing through many Dominicans and at the same time, the inability to eradicate the link to a past African heritage. Haiti's blackness is the dominant force when juxtaposed against the Dominican Republic's 
whiteness, which can be viewed as being in danger of extinction. While both countries were already interpolated by whiteness, Haitian liberators, such as Dessalines, declared all citizens black and heralded blackness as something to be proud of given the nation's history as the first free black republic. Dominicans saw blackness as a color that was the antithesis of progress and therefore sought refuge in the "white” or "light” side of their history and identity. The Dominicans in the novel are thus fighting to maintain an identity which seems positioned to be obliterated by the blackness that the Haitian population represents. The cultural shadow projection is again similar to the German fear of a growing Jewish population. Both histories, that of the Haitian Massacre and the Jewish Holocaust, remain markers on our current paths as a global community that we carry forth with us each day, and they work as shadows to the conscious self that we must confront and name in an effort to reduce the likelihood of history repeating itself. Danticat's novel is then a vehicle to accomplish this preemptive work on behalf of those who seek to eradicate the kind of inhumanity that both the Haitian Massacre and the Jewish Holocaust represent. Although not an empirical history, this historical novel is grounded in tremendous research and an understanding of the ways in which the collective shadow was/is at work.

As mentioned before, however, the collective shadow does not work alone in Jungian philosophy. The collective shadow is always already in play with the personal shadow, the shadow derived from a specific person's lifetime and experiences. The lifetime experiences of Danticat's characters are rooted in the Caribbean and its history. In his essay, “The Known, the Uncertain,” Eduoard Glissant asserts that "the implosion of Caribbean history (of the converging histories of our peoples) relieves us of the linear, 
hierarchical vision of a single History that has roared around the edge of the Caribbean” (66). According to this theory then there would be no single origin or history and the Caribbean creates a space to think of history as something more fluid and less static. The idea helps to connect the personal shadow to the African concept of Great Time and Eduoard Glissant's theories on History vs. history. Glissant notes that History is a "highly functional fantasy of the West but that history as a consciousness at work and history as lived experience" are not solely the business of historians, but of literature as well, as it implicates all the perspectives of the human sciences (65). Great Time is the theory that an overlap between the current generational experiences with those of the ancestral exists so that time is not something to be viewed in a linear fashion but as something that freely moves back and forth, connecting the past, present and future.

In Great Time, history is not a linear production, something to keep in mind while analyzing the Caribbean text. The collective shadow works with the ideologies and understandings of history that has been adopted by a group of people. It is interesting then to consider how generational and ancestral experiences are in conversation with the collective shadow. As Amabelle works through her own personal shadows stemming from survivor's guilt and the need for self-preservation, she also interacts with shadows in place long before her existence. Her country's own understanding of race and Haitians' place in history as the first black republic versus the Dominican Republic's concept of race and the devaluation of black identity come to a head through her experiences. Through the act of re-writing history in The Farming of Bones, Danticat brings the concept of Great Time into the mixture of how a particular moment in Haitian history, the 1937 massacre, can be read as manifestations of a Dominican collective shadow. 
Additionally, Caribbean scholars have identified other sources of shadow theories as viable and efficacious frameworks for interpreting Caribbean cultures and historical realities. As Ann Casement acknowledges in her article, "The Shadow," "the phenomenon of shadow also varies from one culture to another" (96). The Caribbean space comes with its own set of ideas of the shadow that cannot and should not be ignored for the sake of a Western interpretation of events. It is important for our understanding of the characters and their own relationship with the collective shadow that the Caribbean, in this case Haitian context of the shadow is brought into the present study. There is to be a parallel look at the Western and Afrocentric Caribbean ideas about the shadow. Thus, to proceed with the application of Western psychoanalysis to the Caribbean subject, Jung's shadow theories will be molded and reworked to allow for a more complex reading of the characters and the significance and circumstances of their confrontation with the shadow.

In “Let the Circle Be Unbroken,” Donna Richards states that “The European and African world-views are so different, in such crucial aspects, that explanations of the African world-view which use Western definitions are blatantly absurd” (255). When we consider this and look at the shadow in terms of racial constructs, it is important that we acknowledge the bias in the language used to refer to the shadow. Though the "light side and dark side are intermingled" in psychological reality, "in psychological terms, white is consciousness, which is cast as positive; black is unconsciousness, which is cast as negative, dirty, perverse, forbidden” (54). It is easy to see how the language used to discuss the shadow complicates the lens through which Danticat's characters can be viewed. This language entrapment caused by the words used to describe the shadow 
highlights the necessity of bringing in the African based view of the shadow. In agreement with Casement, Connie Zweig and Steve Wolf's Romancing the Shadow: Illuminating the Dark Side of the Soul, makes the argument that "shadow content is always formed in a cultural context-that is within the beliefs, values, language, and myths of a given group" (53). Given Haiti's complex views of religion and the pervasiveness of the Vodou religion and its philosophical tenets as an oftentimes silent backbone in everyday notions and practices, Vodou understanding of the shadow gives us an important theoretical frame through which to read Danticat's novel.

Catholicism may be boasted as Haiti's main religion, but it is also true that many of the religions practiced in Haiti are influenced in some shape or form by Vodou. Vodou came through Haiti from the Africans brought during enslavement, and spread throughout the budding nation, oftentimes becoming a sign of resistance and unity among the Haitian people. When Haiti declared its independence in 1804, given the times and racist attitudes around the world, usually influenced by the desire to colonize, Haiti received minimal support. In fact, for over 50 years, priests were denied opportunities to serve in Haiti because of the fear of Haiti's potential influence on the other nations where enslavement was still in effect, allowing Vodou to prosper (McCarthy Brown). However, Hollywood and the media continually vilified this system, while most of the actual practices, though ingrained in everyday life, are often kept under wraps or even done without an explicit knowledge of Vodou.

In “Afro-Caribbean Spirituality: A Haitian Case Study”, Karen McCarthy Brown points out that healing seems to be the common business of all religious systems (2). In the understanding of personhood, which resembles Jung's theories on individuation, 
Vodou also plays a role. It is considered to be relational as "the individual person is defined by a web of relationships that includes not only the extended family but also the ancestors and the spirits or saints...personhood is seen as constituted by the dynamic balance of diverse spiritual energies or tendencies” (2). This idea of personhood adds another dimension to Jung's theories. Individuation is not just the merging of the positive and negative aspects of the self, but also the merging of the relationships to the ancestral spirits with the self. It is not enough for the individual to come to terms with who they are but also with who they represent as well, as the current generation. As with Nancy, being exists through the understanding and acceptance of being-with, always already reimagining the Self as we interact with others.

Furthermore, McCarthy Brown asserts that in the Vodou belief, people have many souls. The focus of this study will be on two of those souls, gwo bonanj and ti bonanj. These are literally translated into "big good angel” and "small good angel," respectively. These words become especially important as Danticat also uses this aspect of the Vodou system in one of Amabelle's dream sequences. In a flashback to being sick at a young age, Amabelle recalls imagining a doll. Weir-Soley argues that the doll seems to be Amabelle's guardian angel or ti bonanj who not only reminds Amabelle of herself when she is well, but also protects her from an early death, assuring her that she will live long as she has come close to death (195). In The Farming of Bones, when Amabelle is feverridden and dreams of her mother's smile her mother reminds her that she is meant to live, stating “'Your mother was never as far from you as you supposed...you were like my shadow. Always fled when I came to you and only followed when I left you alone”” (208). Neither of these souls, gwo bonanj and ti bonanj, is cast into the realm of positive 
versus negative or light versus darkness. The strength of these souls is reflected in the fact that they are both presented as good angels, keeping watch or helping the individual keep watch over themselves. The Vodou shadow theory provides a way that frees us from the problematic Jungian terms in order to resist facile binary oppositions.

It is only through death or by the possession from a lwa, or spirit, that the person becomes separated from the gwo bonanj in Vodou. It is said to wander from the body during sleep and possesses the ability to connect with the dead and other people close to the person, appearing in their dreams. Amabelle’s ability to connect with the past and come to terms with her present because of her dreams is a reflection of this ability of the gwo bonanj to wander. It is when she finds rest and is coaxed into her dream states that Amabelle’s present becomes clearer to both herself and readers. According to McCarthy Brown, agitation of the gwo bonanj breaks a person's communication with dispersed family, ancestors, and spirits, so it is not desired (8). "Given these various understandings of the nature and activity of the gwo bonanj, it seems fair to conclude that this dimension of soul is both the consciousness and essential personality of the individual” McCarthy Brown deduces (9). This dimension is not part of the shadow in Jung's theories, but it is a part of the shadow in the Vodou tradition. It speaks more to the collective shadow, though it is not presented as an always unconscious state. Gwo bonanj is a constant, freely flowing force that acts as an active connector for the individual to the past, present and future.

Perhaps the idea behind the ti bonanj most connects to the overall concept of the Jungian shadow. The shadow's dark center is considered to be the gwo bonanj and the paler shadow around the center is the ti bonanj. As the shadow in Jungian theory can be 
used as a scapegoat or in instances of transference, ti bonanj is there for when the burdens of life become too much and acts as a reserve tank, helping the person do what they have to do. "It is an energy or presence within the person that is dimmer or deeper than consciousness, but it is nevertheless there to be called upon in situations of stress and depletion” (McCarthy Brown 9). Hence, the ti bonanj can relate to Jung's shadow theory in that the resources from the reserve tank can be viewed as either positive or negative in helping the individual cope with life's circumstances. What is presented through the conscious being is a manifestation or reflection of the resources pulled from the reserve tank. In one scene, though she may have been weakened and badly beaten, Amabelle silences Odette, a fellow Haitian trying to escape the massacre, and prevents her from crying out so that they will not be found, accidently killing her as she covers her mouth and nose to silence her. "All I had wanted was for her to be still, to do her part in helping us live” she mournfully reflects (202). Amabelle’s ability to will herself to survive as she escapes the horrors of the massacre and crosses into Haitian land is an example of the ti bonanj at work.

Zweig and Wolfe maintain that the "personal shadow is nested within the family shadow, which is nested in the cultural shadow, which is nested within the global shadow” (55). Therefore, it is important to analyze the personal, family, cultural, and collective shadows present in the novel, as they relate to the global shadow and to racial constructs in the larger scheme of things. McCarthy Brown reflects that, different from many ideologies, "in the Vodou worldview the individual is both a separate self and an inseparable part of a family” (11). Thus, individuation is not possible without a reconciliation or understanding of this connection to family. In fact, according to Stanley 
Diamond, "It is through ritual that the unexplainable is « understood », that chaos is made to be ordered within the logic of tradition...that trauma is avoided, crises dealt with and overcome and difficult transitions are perceived as passages between stages of normal growth and development” (qtd.in Richards). Amabelle’s experiences are a then larger part of just her own personal history. They speak to a nation's history, which is connected to the island, and the world. Vodou is derived from African beliefs, in which sacred time is timeless and rests on the notion of interdependence and interrelationship with a cyclical concept of past, present and future. Amabelle's connections to her family, ancestors, and spirits are given the opportunity to collide with those of readers of the text as they explore the shadows informing her experiences, alongside her.

The shadow, in both Western and African ideologies, is a constant companion to the Self. Great Time, which acknowledges an overlap between the current generation or experience with the ancestral, leaves space to investigate this relationship between the shadow and history. Danticat creates a space wherein the collective shadow, which is always already a part of the conscious self, can aptly interact with an African idea of storytelling. Heather Russell asserts in Legba's Crossing, that "storytelling always exists in Great Time, bridging past, present, and future and history, memory, and the imagination” (141). They are all inter-connected. Through the narrative, The Farming of Bones, Danticat not only demonstrates Amabelle's confrontation with her own country's shadows and projections but the Dominican shadow inflicted on her. The shadow at work in this novel is two-fold. It is the Dominican Republic's denial of African ancestry and the resulting fear in both Haitians and Dominicans who refuse to see the facts and realities of their joint and separate histories. 
The characters in the novel are often unable to confront these truths, denials and fears, and the result is detrimental for all involved. We, as readers, are then also presented with the option of confronting this fragmented and fissured community. The Farming of Bones, though a fictional text, allows space for the reader to both interpret what has occurred in the novel, but also gives the tools, means, and lens to connect to this very real topic. It provides readers with a historical background, Amabelle’s personal experience and her inner thought process as an individual living through a time of a racially charged point in the history of Hispaniola. Amabelle works through the past and present racial tensions existing between the two countries to interact with a future left unknown to readers.

Russell states that "the exercise of imagination, engendered by the enactment of storytelling, becomes the mechanism by which the Discourse of race is consummately fissured and replaced with ethical, just, democratized, humanist, empowering discourses” (142). The Farming of Bones presents a historical moment in which the massacre of a group of people was done in the name of race, or an ethnic cleansing. This look at race brings the issue out of the periphery of the lives of the readers and moves it front and center. The ramification of the lack of discourse by the two nations is put on full display. The novel then works with the concept of the shadow both through Danticat's characters and narrative, but also through Danticat's act of writing and publishing this revisionist historical text.

Mattoon in Jung and the Human Psyche sees the shadow as "not only necessary for wholeness but also capable of yielding treasure” (29). However, the goal in confronting the shadow should not be towards individuation or wholeness as in Jungian 
thought. Casement's suggestion here is emblematic of this narrow logic: "only the individual who learns to deal with his/her own shadow has done something real for the world for no one can see straight if they do not see themselves” (99). A real picture of the Self can be seen and understood once we confront the shadows that we consciously or subconsciously ignore. There is no single, one fit for all, result that comes with dealing with the shadow. It is also important to bear in mind that Great Time is not concerned with a simple categorization of problems but with a continual interaction and conversation between the past, present, and future.

Once readers have engaged in conversation about racial constructs, changes can be made in local culture and eventually in global culture through ripple effects. A witness is meant to bear witness, to testify about what's been seen and heard so that decisions can be made and action can be taken. Zweig, referring to the Jungian shadow, states:

For some, doing shadow work might mean sacrificing niceness for honesty; it clearly means sacrificing ego appearances for the authenticity of the self. For others, it may mean sacrificing grandiosity for humility; it clearly means sacrificing naive innocence for the promise of mature wisdom. (56)

The novel, I argue, seeks to achieve movement; movement that is not contingent on a linear concept of time. This can be a movement forward to a time where racial paradigms brought forth by colonization, as a collective shadow, will not be in place with inland and diasporic relations with Haiti. It can also be a movement backward to the moment of Haitian independence, to reclaim the course of history and resulting paradigm shifts. While there is no "inception" date of racial disparities and tensions, the acknowledgement of colonization's role in a massive racial narrative is important. The 
conversation surrounding racial discourse will require time and an active pursuit. It is a movement that sits on the cusp, on the edge, awaiting the moment when it can be propelled to greater, deeper heights, a benefit to all affected by the current racial narrative. 


\section{TEXTUAL ANALYSIS OF THE FARMING OF BONES}

"Everything that we see is a shadow cast by that which we do not see." Martin Luther King, Jr. "Where love rules, there is no will to power; and where power predominates, there love is lacking. The one is the shadow of the other."

Carl Gustav Jung

Danticat's novel, within the first couple of pages, creates a theoretical framework for working with shadow theory. In fact, Amabelle's father is aware of her interest in her own physical shadow from a young age. He warns her that playing with shadows can give her nightmares such as "seeing voices twirl in a hurricane of rainbow colors and hearing the odd shapes of things rise up and speak to define themselves” (4). This idea of being able to hear things that are trying to define themselves is juxtaposed against the racially-laced events that unfold in the novel. Through the analysis of the shadow, of the unspoken or ignored racial disparities in the novel, we, as readers, can come to "hear" the things that are seeking definition and action. The voices may indeed twirl in a hurricane, with a force, as we try to face them in their resulting chaotic beauty, the rainbow of colors. Yet the opportunity to unearth the odd shapes is more than we should pass up. Our opportunity to complete this shadow work speaks to our ability to see the shadows and bring light to the places or the lives over which they have been cast.

The history between Haiti and the Dominican Republic is overwhelmed by a historical pattern of contention that helps readers contextualize Danticat's novel and provides insight for understanding the possible reasons for the Dominican collective 
shadow. By 1937, the Dominican Republic had been free for barely 100 years. This was a freedom consistently marred by the continued attempts of reoccupation from Haiti and Spain and an American occupation. At the time of the massacre, the Dominican Republic was likely trying to assert their power in any way that they could. Given the Dominican Republic’s inclination towards the United States, where racial tensions also ran high, distancing themselves from their proud black neighbor, seemed crucial to the survival of the Dominican Republic. In “Unsilencing the Past: Edwidge Danticat's The Farming of Bones,” Donette Francis points out that unlike US racial politics where one drop of black blood makes one black, in the Caribbean one drop of white blood makes one not-black" (qtd. in Simões 5). In colonial times, many had relegated the label of "black" to former slaves and Haitians, laying claim to more of a mixture of the Spaniard and the Taino or slave. Yet historically, by 1517, when Bartolome de Las Casas proposed the importation of slaves, only 12,000 Taino Indians were reported by census, though Dominicans continued to construct “a Taino-influenced ancestry” (Wucker 65-66). The colonized mindset remained long after the colonizer had left.

According to Torres-Saillant, American commentator Sumner Welles had realized that by the 1920s, there was a contradictory yet viable insinuation in the Dominican Republic that negrophobia can exist independent of racial oppression (1088). Yet, racist actions and moments by the Dominicans exist, fueled by antihatianismo. One such instance is the 1937 massacre discussed in The Farming of Bones. There was a need by the Dominican Republic to demonstrate that not only were Haitians radically Other, but that there was no danger of another reoccupation by Haiti. The presence of so many Haitians, including many who now spoke Spanish and had formed Dominican-Haitian 
families along the border, posed a threat to demonstrating the clear separation between the two countries.

The presence of Haitians and Haitian descendants in the Dominican Republic and their treatment by the Dominicans are explored from the novel’s beginning. Señora Valencia gives birth to twins, Rafael and Rosalinda, in the beginning chapters, with Amabelle acting as a midwife. Yet, the birth of the twins is chronologically preceded by a tragic event that is discovered by Amabelle once Señora Valencia's family has been tended to. In the hurry to reach his wife and witness the birth of his children, Señor Pico barrels down the road, striking Joel, a cane worker, and forcing the other two men with him into a ravine in an effort to get away. Pico, most likely named after the high mountain peak that is in the Dominican Republic, also represents Trujillo's militia, who follow their leader and carry out his plans. On the other hand, the slain Joel is the son of Kongo, a father figure to many of the Haitian cane workers in the Dominican Republic. Kongo represents Africa, a strong connection as an elder to the African heritage, and this is the threat. The idea behind the massacre is to rid the Dominican Republic of this tie to the African presence. Not surprisingly, the massacre is foreshadowed by the lack of regard for the death of Kongo's son Joel. If Kongo is Africa, his children are the issue in the Dominican Republic. As Kongo's child is killed to make way for the new Dominican offspring, so will be the Haitians living along the border.

The birth of the twins in the novel highlights the racial constructs that the Dominican collective shadow casts and forces upon Haitian workers. Amabelle, Señora Valencia's servant, becomes a makeshift but knowledgeable midwife. She plays into the Vodou notion of the sajfanm, the midwife who births the marasa (twins), noting the 
important signs of the birth and playing a role into how their births are interpreted (Houlberg 17). Though she has no prior experience delivering children, she recalls her parents' occupation and comments on the birthing process. The knowledge of her departed loved ones is accessible to her, making her a satisfactory midwife. The gwo bonanj is at work here as she is able to connect with departed family members and she uses the skills they had in her own reality. According to McCarthy-Brown, the gwo bonanj allows "deceased persons or those living at a great distance to appear in dreams" and it is Amabelle's constant dreams about her parents that allow her to recall what has happened in the past when she needs to (8). Thanks to her help, Señora Valencia gives birth to a boy, later named Rafael, and a girl, Rosalinda.

Once Señora Valencia has given birth and the babies have been cleaned, the mother is quickly preoccupied with their appearance. The birth of the twins, and subsequent questions and actions by Señora Valencia and her husband, Señor Pico, can be used to address the issue of identity. It is not far-fetched to make the comparison between the twins and the relationship between Haiti and the Dominican Republic given the description of the twins. "The girl appeared much smaller than her twin, less than half his already small size” Amabelle observes (31). Haiti is about one-third of the size of the Dominican Republic and Haiti has a larger population of dark skin individuals. The color of the twins' skin draws attention to this fact. Rafael's milky skin is favorable while Rosalinda's darker complexion is enveloped in poetic language to mask the reality that she appears to reflect an African heritage. Rafael is a "cherimoya milk color" and Rosalinda is "a deep bronze, between the colors of tan Brazil nut shells and black salsify" (11). It is a denial of blackness that is not loud yet is still insistently and quietly in place. 
Furthermore, not only do the twins differ in skin tone, but they also have the same origin; they shared a womb. In using the term origin, however, I do not wish to imply that the History of Hispaniola begins with colonization. "History [with a capital $\mathrm{H}$ ] is a highly functional fantasy of the West, originating at precisely the time when it alone 'made' the histories of the World” Glissant warns (64). However, I do wish to use the current human metaphor as a starting point of the history between the twins. Señora Valencia is the birth mother of these twins whose relationship seems contentious from the beginning. The two, it appears, were not able to share the "land” or placenta. Señora Valencia's womb was in fact colonized and yielded these two different offspring that once shared a space in relative peace, and when "birthed," in turmoil, begin a history as two separate entities. Unlike Haiti and the Dominican Republic, however, Danticat creates a context where the twins can be separated. Though she is only thought to be pregnant with one child, Señora Valencia's other child, Rosalinda, is born soon after Rafael. It seems as if Rafael has tried to kill Rosalinda from inside the womb. Doctor Javier later comments, "It's as if the other one tried to strangle her" (19). She is born both with a caul and the umbilical cord wrapped around her neck. The odds are against her to survive. Danticat seems to imply here that Rafael has attempted to radically remove himself from the Other, the darker side of his people. The twins are then a challenge to the idea of a pure "Dominican-ness." However, this is not to say that a Dominican culture different than that of Haiti does not exist. Jean-Luc Nancy argues in "Eulogy for the Mêlée” that: Every culture is in itself "multicultural", not only because there has always been a previous acculturation, and because there is no pure and simple origin [provenance], but at a deeper level, because the gesture of culture is itself a mixed 
gesture: it is to affront, confront, transform, divert, develop, recompose, combine, rechannel. (152)

Thus, the challenge here is to the idea of a Dominican "essence" void of a history of enslavement. Rafael, named after the Generalissimo, does not cry when he is born and it is not until the birth of Rosalinda that he does so. "The firstborn wailed as I drew another infant from between Señora Valencia’s thighs” Amabelle notes (10). His pain is then the result of her survival and resilience even in her weakened state.

Señora Valencia's worry about the appearance of her twins is a reflection of the collective shadow. She fears that her daughter is like a chameleon, taking Amabelle's color at the sight of her. "Amabelle do you think my daughter will always be the color she is now? ....My poor love, what if she's mistaken for one of your people?” Valencia asks (12). She does not want this stigma on her newborn because she knows the implications. Valencia highlights this separation that she has also internalized through her questions to Amabelle. It is clear to readers that though she seems to appreciate Amabelle, Valencia in no way believes them to be equals. The term "people,” Nancy argues in Being Singular Plural, "indicates everyone else, designated as the indeterminate ensemble of populations, lineages, or races [gentes] from which the speaker removes himself" (7). Valencia has not merely used "people” however, which would include her in the distancing. By placing the possessive "your" in front of "people," she clearly removes herself from the group in question, distancing herself away from Amabelle, who has been a companion since childhood. She has placed herself in a category other than Amabelle's. It is within these moments of fear, that the unconscious 
feelings of negativity toward Haitians surfaces. The alternate side of her personality, the one wishing to be superior, emerges from the shadows in this moment of doubt and fear.

Though Señora Valencia does not seem to ask or say things out of malice, the fear seems clear. Señora Valencia describes the children to Amabelle as “...my Spanish prince and my Indian princess...The profile of Anacaona, a true Indian queen” (29). She prefers to connect her daughter's skin tone to the Tainos, like many Dominicans, though Don Ignacio casts doubt on Señor Pico's heritage. When Doctor Javier claims that Rosalinda has "a little charcoal” behind her ears, indicating a possible African heritage, Don Ignacio is quick to say this must be from her father's side as Señora Valencia's mother was of pure Spanish blood and could trace her family back to the Conquistadores (17). He however dismisses the whole conversation moments later, calling Doctor Javier's observations impolite. Cederstrom notes that the shadow's projection "is a means by which the psyche can discharge negative elements built up in the unconscious which, unless recognized as one’s own, might .....undermine the beliefs of a society” (31). Señora Valencia needs to cling to this specific version of history that does not acknowledge a possible African heritage from her husband's side. Furthermore, she sheds light on the hierarchy of her relationship with Amabelle by asking her Dominican servant to spend the night by her side, rather than Amabelle, her companion since childhood and the acting midwife of her twins. Although she dismisses it, this is one moment in the text in which Amabelle question her role in society. "Why Juana? Why not me?” Amabelle wonders (41). Danticat seems to write in these thoughts so that readers will question Senora's decision as well. What is the reason for Señora Valencia's rejection of Amabelle? 
In the lens I've chosen to use to interpret these characters, it is implied that although Señora Valencia can reject the Other, the twins, however, ultimately need one another. "The two babies stopped crying when we rubbed the soles of their feet together" Amabelle observes (11). This thus suggests that though the twins were at war, when they are together, sole to sole, they seem to find a peace not possible when they attempt to distance themselves from each other. Furthermore, the separation that Rafael has finally gotten from Rosalinda, through their birth, does not have the desired consequences. JeanLuc Nancy in Being Singular Plural, states that, "Being cannot be anything but beingwith-one-another, circulating in the with and as the with of this singularly plural coexistence” (3). As identity is not fixed, Rafael's attempt to assert a fixed identity, void of the realities that Rosalinda presents, leads to a literal death. It's as though "he simply lost his breath” Doctor Javier observes when Rafael quietly slips away, never waking from his sleep (90). Death comes for the rejecter, Rafael. His “identity” is irreparably lost. This suggests that attempting to achieve a pure identity is therefore not an attainable goal. Neither he nor Rosalinda, who must grow up without her brother, benefits from this rejection. Rafael's death could then be seen as a mechanism to demonstrate that in hurting the other, we hurt ourselves because we are the other. The twins' inability to coexist is catastrophic to all involved. This is the dilemma for Hispaniola, and in a way for the world, which Danticat hints at. The Dominican Republic's inability to confront the collective shadow not only affects Haiti, but the Dominican Republic as well.

One of the issues that The Farming of Bones highlights is the antagonistic sentiment the Haitian presence in the Dominican Republic stirs up. This is further explored in the text in the Generalissimo's radio broadcast. Trujillo's first broadcast is 
aptly presented during Rafi's wake. As Pico, Valencia's husband and one of Trujillo's soldiers, raises the volume, the Generalissimo's voice booms:

You are independent, and yours is the responsibility for carrying out justice...Tradition shows as a fatal fact...that under the protection of rivers, the enemies of peace, who are also the enemies of work and prosperity, found an ambush in which they might do their work, keeping the nation in fear and menacing stability...The liberators of the nation did their part...and we could not ask more of them. The leaders of today must play their parts also. (97)

Trujillo has already formulated a plan to eliminate the Haitians, at this point of the novel, and he is spreading his antihatianismo sentiments through the airwaves. He is calling for Dominicans to remember their past struggle for independence from Haiti. Haitians are cast in the role of the oppressors who, if given the opportunity, will reoccupy the eastern side. Yet, conveniently, it is ignored that oftentimes it is the allure of the Dominican need for laborers on the sugar cane field or elsewhere that draws Haitians to the Dominican Republic. Justice here is at the expense of the Haitians on what has been deemed to be Dominican land, justice as a euphemism for genocide. This is not a matter of asking Haitian migrants to leave, though this may have received mixed results, anyway. This is a call for a radical removal and annihilation. Haitians are vilified and this destructive rage, Nancy states is problematic. Nancy goes on to say that, in such cases, when we call for a rejection of the other:

We no longer look for a singularity of the origin in the other; we look for the unique and exclusive origin, in order to either adopt it or reject it. The other becomes the Other according to the mode of desire or hatred. Making the other 
divine (together with our voluntary servitude) or making it evil (together with its exclusion or extermination) is that part of curiosity no longer interested in disposition and co-appearance, but rather has become the desire for the Position itself. (Being 21)

The mode is one of hatred, and Haitians are no longer other, but Other. Trujillo has dispositioned Haitians in the Dominican Republic. His dogmas seek to heighten Dominican resentment of the Haitians presence, once again on "their side of the island.” This antihatianismo and resentment is steeped in racial prejudice. In attempting to cleanse the Dominican Republic, fictional Trujillo, like actual Trujillo, loses sight of community. As stated in the preface of "The Inoperative Community," Nancy reveals that "The community that becomes a single thing (body, mind, fatherland, Leader...) necessarily loses the in of being-in-common. Or, it loses the with or the together that defines it. It yields its being-together to a being of togetherness" (xxxix).The togetherness that Trujillo seeks is the basis of togetherness that was used by the Nazis. This togetherness radically separates, problematizes, and creates the Other. It is against this very idea of community that both Nancy and The Farming of Bones seem to argue. Community calls for a beingtogether rather than togetherness. Togetherness is steeped in a fixed and solid identity that few, if any can fit into. This form of community yields hatred and loses focus on the being-with as it tries to be something that it cannot ever be. By trying to persuade the Dominican Republic to embrace this particular understanding of community, Trujillo thus forces community to be that single thing and loses the in of being-in-common. Even more of the Dominican collective shadow is recited through Father Romain. He is a Haitian priest who lived in Alegría and was sympathetic to fellow Haitians during 
the massacre. It is later revealed that though he was not killed, he was tortured, held in prison during the massacre and forced to listen to the Dominican indoctrination until he went mad. When Amabelle visits him at first after the massacre, he can only recite these words back:

Our motherland is Spain; theirs is the darkest Africa, you understand? ...Sometimes I cannot believe that this one island produced two such different peoples...We, as Dominicans, must have our own separate traditions and our own ways of living. If not, in less than three generations, our children and grandchildren will have their blood completely tainted unless we defend ourselves now, you understand? (260-261)

This speech reflects the major sentiments behind the massacre. There is a Dominican fear that the Haitian presence poses an evil consequence. Señor Pico, for example, may understand why his distressed wife invites Kongo and the other cane workers to her house after Rafi's death, but this does not stop him from destroying every piece of the imported tea set touched by the workers during their visit (116). Furthermore, the actions committed by the Dominican people, in obedience to their leader, had long before the massacre been attempts to get rid of the Haitian presence.

For example, the town Amabelle lives in, Alegría, is inhabited by Dominicans, Haitians and Dominicans of Haitian descent. In fact, there is a section where the people speak both Kreyol and Spanish, or even a mixture, and these people are referred to as the “non-vwayajé Haitians” (68). The term literally translates to non-traveling Haitians. They are better off than the cane cutters and servants and have better housing. Amabelle recounts, "They were people whose families had been in Alegría for generations: 
landowners, farmers, metalworkers, stonemasons, [etc]” (68). Though many were born in Alegría and some have Dominican spouses, they are still considered as Haitians by both Haitians and Dominicans. To Haitians, these people seem to represent people that have made something of themselves. Dominicans, however, seek to distance themselves from these people born of the same land. "To them we are always foreigners, even if our granmemes' granmemes [grandmother's grandmother] were born in this country...This makes it easier for them to push us out when they want to” one Alegrían man observes (69). As in our reality in 2016, they too recognize what the lack of documentation and access to education means for them.

Danticat's focus on introducing the reality of the town life falls in contrast to the very name of the town, Alegría, meaning joy. Though there is a profession of joy through the town's name, Alegría is often the antithesis of joyful. What comes out of the shadows is sadness, rejection and longing. The people of the town cannot fully categorize themselves as Haitian or Dominican. They understand that the government's refusal of their Dominican status comes at a price for each additional generation that does not have proper paperwork and they have yet to see any changes made in how the government treats them. Their longings reflect the very real plight of thousands of people of Haitian descent living in the Dominican Republic. In the documentary Sugar Babies, Danticat narrates similar sentiments upon which her novel draws:

Ironically, despite some families having lived in the Dominican Republic for 10, 30, 40, 50, even 70 years, and though according to the constitution all children born in the Dominican Republic have a right to its citizenship, the country has arbitrarily chosen to regard Dominican-born children of Haitian ancestry as 
foreigners in transit. It is on this claim that a valid legal status or citizenship is denied, and that these children are not even acknowledged. (2007)

In the novel, written almost a decade before the release of the documentary, Danticat illustrates how the Dominican rejection of the African, the Other, marginalizes this group of people. They exist on the outskirts. They too are a part of the Dominican identity. Yet they only serve as a reminder of the "threatening” Haitian presence. In fact, Father Romain, after his imprisonment and torture during the massacre, later babbles, "They once came here only to cut sugarcane, but now there are more of them than there will ever be cane to cut, you understand?” (260). His conversations after the massacre are reflections of what he has been forced to listen to and repeat as an explanation as to the necessity of the massacre. The uneasiness about the Haitian presence is clear.

Amabelle, as a vwayajé, wayfarer, is always already fixed in a struggle between her Haitian roots and the Dominican land she has inhabited for most of her life. Her lover Sebastien, though at times also a shadow, later becomes, albeit a less tranquil, guardian of her innocence. Donna Weir-Soley argues that "Sebastien is Amabelle’s only link to her history and ancestry, a collective and individual past that is complex, troubled, gloriously and quintessentially Haitian” (189). In working through her cultural history, Amabelle’s perspective of herself and the worlds she inhabits is renewed. He, the representative of this link, is a shadow that Amabelle readily claims and he presumably becomes one of the twirling voices. Sebastien appears in her dreams and holds the remedies for her wounds, whether they are animal bites, fevers, aching joints, digestion or the need for pleasant dreams (282). Though later, she may appear as very naïve about her position as a servant to Don Ignacio’s family, from the outset, Danticat asserts that Amabelle is quite aware 
that there is more than her personal unconscious that accompanies her. The collective unconscious of her Haitian people is also a part of her. Amabelle realizes that their voices are struggling to be heard and that she is a part of this struggle. "I was never naïve, or blind. I knew. I knew that the death of many was coming...it must be known that I understood. I saw things too. I just thought they would not see me” (265). During her time in the Dominican Republic she does not have the tools, or is arguably not ready, to confront these voices. It takes Amabelle the span of 264 pages before she is set to confront these shadows as she finally realizes how many years have passed.

The situation between the Dominican Republic and Haiti is a heightened reflection of race politics in Haiti itself. To provide a fair reading of shadows in the Haitian-Dominican relationship, it is important to examine Haiti's own shadows. Haiti's history is also filled with many of the same struggles they face at the hands of others. Part of the reason for the economic strife and realities stem from the people's own inability to deal with color politics and issues through discourse. Enslavement and the way to rebuild Haiti after independence brought about issues of color for the nation. The new nation was and is continually divided between the mulattoes and the darker skinned Haitians. Though they readily unite against other nations and against clear issues of colonizer versus colonized, when the dust settles, the two camps remain divided. From her time in and studies of Haiti, Zora Neale Hurston stated that the social problems are due to a divide of class and color: "Haiti has always been two places. First it was the Haiti of the masters and slaves. Now it is Haiti of the wealthy and educated mulattoes and the Haiti of the blacks. Haiti of the Champ de Mars and Haiti of the Bolosse. Turgeau against the Salines” (qtd in Pamphile 140). 
Furthermore, as the country is a scapegoat for the Dominicans' inability to deal with a black identity, the Dominican Republic is Haiti's scapegoat for its lack of political power. After the massacre, it is made clear to readers that Stenio Vincent, Haiti’s mulatto president at that time, does not do much for retribution or justice. The patients being cared for by the nuns after the massacre recognize this. Someone laments in the makeshift clinic, "In all this, our so-called president says nothing, our Papa Vincent-our poet--he says nothing at all to this affront to the children of Dessalines, the children of Toussaint, the children of Henry; he shouts nothing across this river of our blood” (212). In Paradise Lost: Haiti's Tumultuous Journey from Pearl of the Caribbean to Third World Hot Spot, historian Philippe Girard remarks that Vincent negotiated a deal with Trujillo, $\$ 30$ to Haiti for each dead Haitian, but reduces the $\$ 750,000$ total to $\$ 525,000$ in order to collect the money quicker, though the Haitian people would never see this money (91). The characters, who cling to the stories of past achievements and heroes, seek a place in the Dominican Republic where they can create a more stable life. "They have so many of us here because our own country-our government-has forsaken us...” one person observes (178). Though forced to endure unfair treatment in their host country, the people grumble amongst each other but also accept this treatment, preferring to deal with the unfair treatment rather than a life in Haiti full of economic strife and unstable, corrupt government shifts. As Tibon, a character Amabelle comes across who is also trying to save himself from the massacre observes, "The poor man, no matter who he is, is always despised by his neighbors. When you stay too long at a neighbor's house, it’s only natural that he become weary of you and hate you” (178). 
Tibon's tacit acceptance in light of a history of not only resistance but also pride in self, has devastating consequences. Lorelei Cederstrom suggests, in Jungian Archetypes in 20th Century Women's Fiction: The Persona, the Shadow, the Animus, and the Self, that “Ultimately, however, after a painful recognition of one’s own part in these projections, the dark and negative shadow can be assimilated and controlled, both individually and culturally” (32). It is not until they are faced with extermination that many Haitian characters openly refuse to suffer through the Dominican collective shadow imposed on them. "No kneeling!” Unel shouts when the Dominican soldiers try to round him and his men up (154). "Pèsi” Odette mouths as she dies, "a provocation, a challenge, a dare" (203). "It would take too much to kill me...I am one of those trees whose roots reach the bottom of the earth. They can cut down my branches, but they will never uproot the tree. The roots are too strong, and there are too many," one of the survivors in the makeshift hospital brags, recalling Toussaint Louverture’s words (212). These characters represent the Haitian spirit of pride and resistance that Amabelle has not yet connected with. She does not connect to this collective pride and memory, the positive shadow, until after the massacre and a forced return to her birthplace, the Cap, home to the Citadel, Haiti's massive structure and symbol of resistance. Amabelle has used dreams, draped over her sight and carried like an amulet against evil, to make it through her ordeal (265). However, the same ammunition also impedes her from fully connecting to her birthplace, not just as a spectator but as a part of the history of the Haitian people.

In compliance with Jung's shadow theory and Great Time, the novel also uses dreams and projections based on personal and cultural historical ties to bridge the gap between past, present and future. Mattoon observes that "in dreams, according to Jung, 
the shadow often appears as a person whom the dreamer does not like, and who, often, is of the same gender as the dreamer" (28). One of Amabelle’s reccurring dreams, which she labels, herself, as a shadow, is of the sugar woman. Given the fact that the history between the Dominican Republic and Haiti has a lot to do with the sugar industry, it is poetic that one of Amabelle's shadows is a sugar woman. "Around her face, she wears a shiny silver muzzle, and on her neck there is a collar with a clasped lock dangling from it” Amabelle narrates (132). The sugar woman pretends to kiss someone taller than herself and tells Amabelle, when asked, that the muzzle had been given to her long ago to prevent her from eating the sugarcane. She claims that Amabelle is her eternity. In light of these ideas of the shadow, the sugar woman seems to represent an inability to speak up. Her silence is two-fold. On one hand she is a sugar woman but yet has been forbidden from eating the sugarcane. Likewise the Haitian cane cutters find work in the Dominican Republic, but yet the migrants are treated unfairly and made to feel unwanted. On the other hand, the sugar woman continuously wears the muzzle and nothing is said of the lock dangling from her neck. Amabelle likewise is aware of the treatment that the vwayajé, non- vwayajé, and even she herself earns at the hands of the Dominicans, but seemingly appears to have nothing to say in response. The conscious self here is damaging because of a lack of connection and interaction with the collective unconscious caused by her displacement. Logic would call for a key if there is a lock. The key is discourse, made through the confrontation with the shadow. Though at first Amabelle is afraid of the sugar woman, in alignment with Mattoon's perception of the shadow, it is later implied that she in fact is the sugar woman. Like the sugar woman who dances the kalanda, upon hearing years later of Trujillo’s assassination, Amabelle finds herself doing 
this dance also. She has also recognized her silence in the face of oppression and vows to get back to Alegría to give testimony to Metrès Dlo. She receives an approving kiss from the Legba figure, the tall professor, mirroring the sugar woman's actions or prophecy (285). Amabelle has therefore found the key to the lock that has been around her neck since Sebastien's disappearance. She can now name her experiences, her shadows, and the collective shadow she has faced. 


\section{CONCLUSION: INTROSPECTION AND DISCOURSE}

“A fully functional multiracial society cannot be achieved without a sense of history and open, honest dialogue.”

Cornel West quote

It is not without complications that Trujillo's orders are carried out during the massacre. Machetes and other means have to be used against Haitians to later assert that their deaths could not be at the hands of a Dominican military armed with firearms. Furthermore, people are forced to say the word perejil (parsley in Spanish) to differentiate between Haitians and Dominicans, who pronounce the " $r$ " differently. "We used pesi, perejil, parsley... all this we savored our food, our teas, our baths, to cleanse our insides as well as our outsides of old aches and griefs...to wash a new infant's hair for the first time and--along with boiled orange leaves--a corpse's remains one final time” Amabelle notes (62). It is this same parsley that is later jammed into her throat by the Dominicans who try to thwart her escape into Haiti, taunting her to pronounce the word in Spanish. As many Haitians could not roll the ' $r$ ' in perejil, it betrayed them to the Dominican aggressors. "Perhaps the Generalissimo in some larger order was trying to do the same for his country” Amabelle ponders as she rationalizes that perhaps the massacre was Trujillo’s attempt at cleaning the country from the inside out (203). It is not color that is then the determining factor as to whether someone lives or dies, but language becomes this factor. As language is what is used to draw lines, separate, and ultimately reject, however, it is also the tool that must be used to stand up to the atrocities being faced as well. "He asked for "perejil,” but there is much more we all knew how to say. 
Perhaps one simple word would not have saved our lives. Many more would have to and many more will,” Amabelle decides (265).

Danticat indicates that it is through the "telling" that Amabelle is able to confront the good and the bad, the glorious and the shameful. It is during her return to Haiti that Amabelle realizes that she has in fact, deep inside, been very aware of her position in Dominican Republic and of the impending massacre. Yet she chose to ignore the signs because she did not believe she had a place to turn to if she did. Yves deals with the massacre by refusing to talk about it afterwards. He can no longer stand the scent of sugarcane, he loathes parsley, he cannot listen to Spanish being spoken and he cannot swim in rivers. Amabelle, on the other hand, discovers that the slaughter is hers to pass on and that her heaven is the veil of water and "to step across it and then come out is what makes [her] alive” (265). Amabelle “tells” her story, and the story of many others, to Metrès Dlo, the Mistress of the Water. "I dream all the time of returning to give my testimony to the river, the waterfall, the justice of the peace, even to the Generalissimo himself” she confesses (264). Haiti and the Dominican Republic’s separation geographically falls along the Massacre River (Rio Masacre), a point that both separates and ironically unites the two countries in their historical struggles. April Shemak observes in "Re-membering Hispaniola: Edwidge Danticat's The Farming of Bones”, that "the river is a place of remembering... [which] necessitates the "re-membering" of the shared island history” (105). This shared history of bloodshed through both the ordered massacre and previous battles with Haitians as they sought their own independence and the occupation of the Dominican Republic, stems from the issue of color. It is precisely at this site that Amabelle is driven to give her testimony. She observes that "It is perhaps 
the great discomfort of those trying to silence the world to discover we have voices sealed inside our heads, voices that, with each passing day, grow even louder than the clamor of the world outside” (266). The river is thus the carrier, both figuratively and literally, a connector of the histories of the Haitian people and the diasporic lands they inhabit. She carries what has been emptied into her, hopefully, as Amabelle desires, not to be scattered by the winds or remain forever buried beneath the sod (267).

The Farming of Bones invokes the Legba figure, guardian of the crossroads, through the character of the professor granting the kiss to Amabelle's voyage and the “cleansing” confession at the river. The river is a space where the gwo bonanj are sent once they are ritually separated from the body (McCarthy Brown 9). Donna Weir-Soley, in Eroticism, Spirituality, and Resistance in Black Women's Writings, states that "Legba is the loa who controls chance, change and destiny. He is the one who intercedes on behalf of humans before any action can take place” (207). The professor, an individual who is seemingly an eccentric being to others, holds the key to Amabelle’s legacy. Amabelle has spent years simply going through the motions in life, only to realize one day that twenty-four years have passed since the events of the massacre. She notes that she heard “The title belonging to an elder- a “Man” before her name and this helps her to begin her journey back to Alegría (269). As Amabelle literally and psychologically confronts her past, upon her return to the Dominican Republic, the kiss from the madman who is called the professor unlocks her passage to the waters to which she has longed to return.

Throughout the novel, Amabelle struggles to come to terms with the shadows of the cultural histories that have provided the space for these particular events in her life. It 
is through this cross of time, the personal and the collective shadow that Amabelle's story is able to speak to the greater, more global tragedy of color politics. She confronts these shadows in the wake of the Massacre as she tells her story to Metrès Dlo, Mistress of the Water, who in turn is the keeper of many histories and shadows. It is through this act of naming and telling, this naked confession, that Amabelle is able to confront the shadows she faces. The confession to Metrès Dlo of her entire life story, carries with it, historical baggage from the history of enslavement. Massacre River empties into the Atlantic Ocean, the site of many deaths during the slave trade. Therefore, the river carries the stories of the 1937 massacre, and of previous battles and of the slaves killed during the trade. These histories are all mixing and Amabelle's cleansing comes about at this site because the stories have all been buried there. It is not surprising that in Vodou practices, in dealing with the lwa, its burial place is at the bottom of a river. Amabelle is hence reconnecting, unearthing, this collective history to add her own story. As the waves crash and ebb away, her story, like the story of those before her, also moves across time and space, joining the stories of millions. There is an urgency to confess to this water mistress that has the ability to take her story and that of many others to new heights, new witnesses.

Danticat's use of the Legba figure in Amabelle's act of bearing witness is then an imperative or call to action by the readers. Having experienced Amabelle's own confrontation, readers now have the tools to confront these same collective shadows present and shouldered by Haitians in the twenty-first century. Whether a reader was exposed to the racial climate in Hispaniola previously, or became exposed because of The Farming of Bones, a light has been cast into the darkness. Amabelle's story has been 
written and it is now her readers turn to write a future stemming from their own confrontations with the collective shadow projected on Haitians in Hispaniola and abroad. The goal of looking into the relationship between the collective shadow and racial politics is not to leave the histories behind and revel in the fact that these moments have passed, but to move forward with them and engage in discourse meant to challenge the way people think about the dynamics of the Dominican Republic's relationship with Haiti. Readers can then also engage in discourse about how racial constructs may affect their lives and their understanding of other issues closer to home, as well. As Jacques Derrida, the French theorist, argues, we come into being in a world that readily employs language. Our specific modes of operating are already invested in a particular frame of reference. Language both frees and traps us, allowing us to transcend barriers. The witness (readers), having heard this story, must bear witness for the witness (Amabelle). Thus, it is the testimony and subsequent action of the reader, as witness, that becomes of great importance.

Danticat is seemingly calling her readers to action, to open up discourse about racial constructs. The role of Danticat's works as calls to action is further supported by several of her interviews and her works mentioned in the introduction to this thesis. In an interview with Marita Golden in The Word, Danticat expresses that:

It is the duty of every truly free citizen to read, especially to read beyond [our] borders, to read and extensively. Writing is our footmark in the world...Reading is a place where you can have a village and be an individual at the same time, and it's totally transformative. It changes who you are, and you can reach out to the larger world" (72-74). 
Kathleen Renk in Caribbean Shadows \& Victorian Ghosts, examines the relationship between the Caribbean woman writer and her work as a reworlding of worlds. In their recreation of the Third and the dominant world, she asserts that Caribbean woman writers are not only "writing themselves into being" but also "writing a new vision of the world that breaks down the remnants of colonialism, the binary oppositions, and static notions of family, nation, race-color, and gender” (27). Their works therefore stand to illuminate and transform the present as I argue Danticat does through The Farming of Bones. The problems that are tackled are issues not just localized to the Caribbean space. In conjunction with Renk's views on the Caribbean writer, Danticat, in Create Dangerously, sees the immigrant artist's role as that of one who can create dangerously for those that read dangerously. Then, "somewhere, if not now, then maybe years in the future, a future we may have yet to dream of," someone may risk their life to read these texts and give these artists a passport that makes them honorary citizens of the reader's culture," she writes (10). The text itself is a tool, a means by which readers can enter into a conversation worth discussing. It is their passport into a land of social justice.

Writing from the United States, in English, a language that large numbers of the Haitian Diaspora are now familiar with, provides an imperative to tell a history, not History, which relays the experiences that have driven the Haitian people to the different diasporic lands where they are at times confronted with the racial paradigms developed from colonization. Carl Jung asserts that:

If you imagine someone who is brave enough to withdraw all his projections, then you get an individual who is conscious of a pretty thick shadow. Such a man has saddled himself with new problems and conflicts. He has become a serious 
problem to himself, as he is now unable to say that they do this or that, they are wrong, and they must be fought against. He lives in the "House of the Gathering." Such a man knows that whatever is wrong in the world is in himself, and if he only learns to deal with his own shadow he has done something real for the world. He has succeeded in shouldering at least an infinitesimal part of the gigantic, unsolved social problems of our day. (Collected Works 140)

Haitians migrate to other countries besides the Dominican Republic and the resulting clash with these migrations yields results steeped in racial constructs. Casement claims that "recognition of the shadow leads to humility and genuine fear of what lies in the depths of humanity. It is ignorance of this that is the most dangerous thing for humans" (102). Danticat's novel itself creates a space for its readers to explore their own constructs about race.

In Legba's Crossing, Heather Russell argues that to break the paradigm of race, the antithesis of freedom, there is to be a coextensive act of naming and renaming reality, where stories bleed into one another to breathe life into the body politic, the imagined and imagining of "community" (143). Danticat, through The Farming of Bones, sets out to do this work of breaking the paradigm of race. It is up to the reader to decide whether they want to engage in this discourse. Cederstrom warns that "even a glimpse of this dark face of the shadow is often so frightening that the seeker is tempted to reaffirm the mask of the persona and hide behind the prejudices of one’s community rather than face the dark unknown parts of the self” (31). People, however, cannot separate themselves from a shadow. Like language and our histories, we are born in the world already a part of this 
discourse that our lives and experiences build on. We coexist together and it is important to scrutinize the moments where we seem unable to.

Danticat provides readers with the opportunity to act, to begin this shadow work, through The Farming of Bones. Danticat's call to action from the readers through the text, not only highlights her activism in the Haitian community but also the global reach of her advocacy on behalf of Haiti. It remains relevant given the current political events taking place in the Dominican Republic regarding residency paperwork and the continued persecution of Haitians descendants in the country. The hard truth is that race, ethnicity, culture and history continue to color the relationship between the Dominican Republic and Haiti. While I believe that the call for action and reflection on how we process history and color disputes extend beyond the borders of Haiti and the Dominican Republic, it makes sense to begin the discussion there. Haiti’s social ills are amplified by these very issues and as a result the way in which the world views Haiti is also affected. The tensions brought up in The Farming of Bones are all the more important for readers to continue to discuss today. Given all of Danticat's works, including many not mentioned in this thesis, it is my belief that Danticat wants her readers to grasp this opportunity that they have been given to become social justice seekers like she has been. 


\section{REFERENCES}

Casement, Ann. "The shadow”. The handbook of Jungian Psychology: Theory, Practice and Applications. London: Routledge, 2006. Print.

Cederstrom, Lorelei. Jungian Archetypes in 20th Century Women's Fiction: The Persona, the Shadow, the Animus, and the Self. Lewiston, N.Y: Edwin Mellen Press, 2002. Print.

Danticat, Edwidge, Julia Alvarez, Junot Diaz, Mark Kurlansky and Anìbal De Castro. Letter. “Two Versions of a Dominican Tale.” New York Times 1 November 2013 New York ed.: A30. Print.

Danticat, Edwidge. The Farming of Bones. New York, NY: Penguin Books, 1998. Print.

---. Create Dangerously: The Immigrant Artist at Work. New York: Vintage Books, 2011. Print.

De Greff, Dana. “Edwidge Danticat On The Dominican Republic: 'Government Is Trying To Erase A Whole Segment Of History’.” Miami New Times. Miami New Times, 12 October 2015. Web. 18 Nov. 2015.

Derrida, Jacques. "Poetics and Politics of Witnessing." Sovereignties in Question. Ed. Outi Pasanen and Thomas Dutoit. New York: Fordham University Press, 2005, pp. 6596. Print.

Duany, Jorge. "Racializing Ethnicity in the Spanish-Speaking Caribbean: A Comparison of Haitians in the Dominican Republic and Dominicans in Puerto Rico." Latin American and Caribbean Ethnic Studies. 1.2 (2006): 231-248.

Gellert, Michael. " The Eruption of the Shadow in Nazi Germany.” Psychological Perspectives. 37 (1998): 1-15. Print.

Girard, Philippe R. Paradise Lost: Haiti's Tumultuous Journey from Pearl of the Caribbean to Third World Hot Spot. Houndmills, Basingstoke, Hampshire, England: Palgrave Macmillan, 2005. Print.

Glissant, Edouard. “The Known, the Uncertain.” Caribbean Discourse. Charlottesville : University Press of Virginia, 1989. Print.

Golden, Marita. The Word: Black Writers Talk About the Transformative Power of Reading and Writing : Interviews. New York: Broadway Paperbacks, 2011. Print.

Heinl, Robert D, Nancy G. Heinl, and Michael Heinl. Written in Blood: The Story of the Haitian People, 1492-1995. Lanham, Md: University Press of America, 2005. Print. 
Houlberg, Marilyn. "Maguique Marasa: The Ritual of the Twins and Other Sacred Children." ," Fragments of bone: neo-African religions in a new world. Ed. Patrick Bellegarde-Smith. Chicago, Illinois: University of Illinois Press, 2005. 1529. Print.

James, C L. R. The Black Jacobins: Toussaint L'ouverture and the San Domingo Revolution. New York: Vintage Books, 1963. Print.

Jung, C.G. "Psychology and Religion: West and East.” The Collected Works Of C.G.Jung. Volume 11. Trans. R. F. C. Hull. Princeton: 1958. Print.

Mattoon, Mary A. Jung and the Human Psyche: An Understandable Introduction. London: Routledge, 2005. Print.

McCarthy-Brown, Karen. “Afro-Caribbean Spirituality”. Vodou in Haitian Life and Culture: Invisible Powers. New York: Palgrave Macmillan, 2006. Print.

Michel, Claudine, and Patrick Bellegarde-Smith. Vodou in Haitian Life and Culture: Invisible Powers. New York: Palgrave Macmillan, 2006. Print.

Nancy, Jean-Luc. “Eulogy for the Mêlée.” Being Singular Plural. tr. Robert D. Richardson and Anne E. O’Byrne. Palo Alto, CA: Stanford University Press, 2000. 145-158. Print.

---. "Of Being Singular Plural.” Being Singular Plural. tr. Robert D. Richardson and Anne E. O’Byrne. Palo Alto, CA: Stanford University Press, 2000. 1-100. Print.

---. "Preface”. Preface. The Inoperative Community. Minneapolis: University of Minnesota Press, 1991. xxxvi-xli. Print.

Pamphile, Léon D. Haitians and African Americans: A Heritage of Tragedy and Hope. Gainesville: University Press of Florida, 2001. Print.

Papadopoulos, Renos K. The Handbook of Jungian Psychology: Theory, Practice and Applications. London: Routledge, 2006. Print.

Renk, Kathleen J. Caribbean Shadows \& Victorian Ghosts: Women's Writing and Decolonization. Charlottesville: University Press of Virginia, 1999. Print.

RICHARDS, Dona. "Let the Circle Be Unbroken : The Implications of African-American Spirituality”. Présence Africaine 117/118 (1981): 247-292. Web...

Rivero, Daniel. "Junot Diaz and Edwidge Danticat jointly speak out against Dominican Republic refugee crisis.” Fusion. Fusion Media Network, 25 June 2015. Web. 18 Nov. 2015. 
Russell, Heather. Legba's Crossing: Narratology in the African Atlantic. Athens: University of Georgia Press, 2009. Print.

Serrano, Amy, and Edwidge Danticat. The Sugar Babies: The Plight of the Children of Agricultural Workers in the Sugar Industry of the Dominican Republic. Miami, Fla.: Siren Studios, 2007.

Shemak, April. "Re-Membering Hispaniola: Edwidge Danticat's The Farming of Bones." MFS Modern Fiction Studies 48.1 (2002): 83-112. Project MUSE. Web. 25 Apr. 2011. <http://muse.jhu.edu/>.

Simões, Maria Cláudia. "Remembering the forgotten: a literary representation of politics in The Farming of Bones, by Edwidge Danticat.” Anais do Simpósio Internacional Literatura, Crítica, Cultura V: Literatura e Política, May 2011, Rio de Janeiro, Brazil. Estudos Literários, na Faculdade de Letras da Universidade Federal de Juiz de Fora, Darandina Reviste Electronica, 2011. Print.

Toress-Saillant, Silvio. " The Tribulations of Blackness-Stages in Dominican Racial Identity." Callaloo. 23.3 (2000):1086-1111.

Weir-Soley, Donna. Eroticism, Spirituality, and Resistance in Black Women's Writings. Gainesville: University Press of Florida, 2009. Print.

Wucker, Michele. Why the Cocks Fight: Dominicans, Haitians, and the Struggle for Hispaniola. New York: Hill and Wang, 1999. Print.

Zweig, Connie, and Steve Wolf. Romancing the Shadow: Illuminating the Dark Side of the Soul. New York: Ballantine Books, 1997. Print. 